\title{
A study on the effects of intellectual capital efficiency on economic performance
}

\author{
Parviz Piri $^{\mathbf{a}^{*}}$, Maryam Yokhaneh Alghyani ${ }^{\mathrm{b}}$, Samaneh Barzegari Sadaghiani ${ }^{\mathrm{c}}$ and Sayed Ahmad Hasan \\ nejad $^{\mathrm{d}}$
}

${ }^{a}$ Assist. Prof. \& Faculty Member, Department of Economy and Management, University of Urmia, Urmia, Iran
${ }^{b}$ Sama technical and Vocational Training College, Islamic Azad University, Urmiah branch, Urmia, Iran
${ }^{c}$ M.Sc. Student, Department of Economy and Management, University of Urmia, Urmia, Iran
${ }^{b}$ University of Economic Studies, Tehran, Iran

\section{H R O N I C L E}

Article history:

Received 5 January 2014

Received in revised format

8 March 2014

Accepted 16 March 2014

Available online

18 March 2014

Keywords:

Capital

Economic performance

Human capital

Intellectual capital

Structural capital

\section{A B S T R A C T}

Intellectual capital plays essential role in corporate performance and this paper examines the impact of intellectual capital and its components on the ratio of corporate operating profit on sales as an indicator of economic performance. The study was accomplished among 1035 companies listed on Tehran Stock Exchange and by using the Pulic-2004 model over the period 2005-2012. The results indicate that intellectual value added coefficient, as an indicator of intellectual capital efficiency, preserves a positive effect on sales and efficiency of structural capital and capital employed maintains a positive and meaningful effects on different financial ratios.

\section{Introduction}

After the Industrial age, societies have entered the knowledge and information age, physical and knowledge capitals as the most important capitals have alternated financial capitals in modern economic (Petty, \& Guthrie, 2000). In the competitive and mutable world, intellectual capital has a special place in business guidance (Murthy \& Mouritsen, 2011). Nowadays, knowledge is a new tool for the evolution of the company and there is no doubt that successful firms are constantly intended to innovate, and instead of absolute dependence on assets, they depend on new technologies such as their employees' skills and knowledge (Moore \& Craig, 2008). Intellectual capital has been considered as an indicator of firm's quality and performance (Pulic, 2004). Intellectual capital and its components including human capital and structural capital plays essential role in corporate performance and influences on the economic performance (Murthy \& Mouritsen, 2011). Therefore, it

*Corresponding author. Tel: +98914-439-0473

E-mail addresses: p.piri@urmia.ac.ir (P.Piri) 
is essential to evaluate intellectual capital and to identify its effects on this dimension of the company, in the view of existence and the nature of this relationship. It is important in the view of stakeholders such as managers, policy makers, and investors who assess firms and their investment. Therefore, the issue that the following study is going to find out is find out whether there is any relationship between intellectual capital and economic performance of companies.

\section{Measurement of intellectual capital}

Measurement of intellectual capital shed light on approving corporate's ability in achieving its strategic goals, development of research and development activities, providing basic information to revision of projects and approving emphasize on educational programs (Paturel \& Ferchichi, 2013). Intellectual capital can be measured based on indirect methods, direct methods as well as privilege cards.

\subsection{Value Added Intellectual Capital method (VAIC)}

Value Added Intellectual Capital method (VAIC) was first introduced by Pulic (1998), and it is one of the direct measurement methods. On one side, the model creates a relationship between customer and product or service, and on the other side, it is the relationship between created value and applied resources in production or service. Pulic (2000) considers value added as the most appropriate indicator of success in business. In the conceptual VAIC model, different intellectual perspectives including structural capital, human capital, physical capital, and financial capital are investigated with the following relationship

$V A=O P+E X+D+A$,

where $V A$ represents value added, $O P$ states operating profit, $E C$ stands for employees' cost, $D$ is associated with depreciation and finally $A$ represents amortization. In addition, Human capital is calculated as follows,

$H C E=V A / H C$,

where $H C E$ and $H C$ are human capital efficiency and human capital, respectively. Finally, structural capital efficiency $(S C E)$ based on structural capital $(S C=V A-H C)$ and value added $(V A)$ as follows,

$S C E=S C / V A$,

In our survey, capital employed efficiency (CEE) is measure as follows,

$C E E=V A / C A$,

where CEE is an indicator of value added, which is created by one physical and financial unit of capital or applied capital. In order to calculate the total efficiency of creating value, intellectual value added coefficient, three calculated efficiency indicators must be summed together as follows,

$V A I C=H C E+S C E+C E E$.

\section{Research background}

Bontis et al. (2000) performed a survey and reported that development of structural capital positively associated with the performance of the company by neglecting the industry type. Firer and Williams (2003) argued that physical capital could be considered as the main influencing source on performance of companies in South Africa. Rahmani Zarangh (2009) studied the relationship between intellectual capital and firms' market value at Tehran Stock Exchange (TSE) over the period 20032007 and reported a meaningful and positive relationship between the value added by intellectual capital and market value of companies. Setayesh and Kazem Nejad (2009) in an investigation of firms listed at TSE over the period 2001-2006 found a positive effect of intellectual capital on asset 
returns, asset turnover, and future performance of companies. Abbasi and Galdi Sedghi (2010) in an investigation studied the impact of efficiency of each element of intellectual capital on the financial indicators of firms listed on 99 firms listed on TSE over the period 2000-2003. The results indicated that efficiency of each element of intellectual capital had a positive and meaningful effect on the rate of return on owners' equity. Efficiency of physical capital and human capital coefficient maintained a positive effect on earnings per share (EPS). However, the effect of efficiency of the structural capital coefficient was meaningful and negative. The result also implied that firms, which had a higher level of intellectual capital, preserved a better financial performance. Makki and Lodhi (2009) in an investigation some companies listed at Pakistan Stock Exchange reported a major impact of intellectual capital on investment returns. Zéghal and Maaloul (2010) reported that intellectual capital had a positive impact on financial and economic performance. Mojtahedzade et al. (2010) studied the relationship between intellectual capital and its elements with the performance of the insurance industry in managers' viewpoint. They reported that intellectual, human, customer, and structural capital in separate and independent review had a significant relationship with performance, while in simultaneously studies, merely the relationship of structural capital and human capital with performance was significant. Ahangar (2011) in an investigation on one Iranian company in a period of thirty years, found a major effect of intellectual capital on profitability and productivity. Maditinos et al. (2011) studied 96 Greek firms at the Athens Stock Exchange in a period of three years, and found a positive relationship between efficiency of human capital and financial performance of the company. Wang (2011) studied Taiwan firms in a period of eight years and found that the efficiency of structural capital mainted a positive impact on the performance of the company. Bin Ahmad and Mezeal Mushraf (2011) in an investigation in Malaysia by studying 320 companies, reported a positive relationship between intellectual capital and performance of the company. Murthy and Moritsen (2011) in a case study found that financial and physical capital had not only an effective factor in intellectual capital, but also they helped improvement of firms. In a comprehensive study of 3100 small and medium companies in Kenya, Mojtahedzade et al. (2010) reported a positive relationship between intellectual capital and growth of these companies. Ahuja and Ahuja (2012) performed a survey in a period of 4 years in the banking sector in India and reported a positive impact of efficiency of intellectual capital on future performance. Shakina and Barajas (2012) studied 752 Russian and European firms in a period of 6 years, and reported a positive relationship between the quality of intellectual capital and performance of the company.

\section{Research Hypotheses}

Based on literature review, the main hypothesis of the survey is as follows,

1. There is a positive relationship between intellectual value added and the ratio of operating profit to sales.

Therefore, the main hypothesis can be divided in three secondary hypotheses as follow:

1.1. Human capital efficiency of company has a positive relationship with the ratio of operating profit to sales.

1.2. Structural capital efficiency of company has a positive relationship with the ratio of operating profit to sales.

1.3. Employed capital efficiency of company has a positive relationship with the ratio of operating profit to sales.

This research is applied and empirical scope type to test the relationship and correlation between intellectual capital and economic performance of company. Intellectual value added coefficient method is also used to evaluate intellectual capital and to determine its efficiency. Required data was attained by annual financial reporting of TSE listed firms, available over the period 2005-2012. 
Because of fundamental activity differences, Investing companies, financial institutions, and banks were excluded and 1053 firm-years were considered to be studied.

\subsection{Dependent variable}

Operating Income to Sales (OIS) ratio is considered as dependent variable as an indicator of economic performance of the company, which is equal to the ratio of operating profit to total sales.

\subsection{Independent variables}

There are four independent variables including Intellectual value added coefficient, Efficiency of human capital, Efficiency of structural capital and Efficiency of employed capital.

The correlation between variables initially has been examined and correlation statistical tables using Pearson and Spearman correlation coefficients have been presented. Meanwhile, if the significance level is less than 0.05 , correlation would be significant. In order to examine the research hypothesis, regression method has been used and in this method, first the total regression model must be tested, which is accomplished with the regression ANOVA table. Then the significance of each independent variable coefficient must be verified, which is executed by coefficients table and when the significance level is less than 0.05 , the significance of coefficients and linear relationship between variables will be confirmed.

One of the regression assumptions is independence of errors. If Durbin-Watson statistic lies between 1.5 and 2.5, lack of correlation assumption is accepted. Another regression assumption is the normality of errors that must have an average of zero. For this purpose standard value of errors must be calculated, data distribution and normality charts are drawn and then both charts be compared. The next test before using regression is collinearity test. If Variance Inflation Factor (VIF) be lesser than 10 , it could be deduced that there would not be any special problems if regression were used for testing the research hypothesis. In order to use regression, distribution of dependent variables must be normal. Using a sample of at least 30, is about to solve this problem. In this research for data entry and some calculations, Excel software is used and also SPSS software is used for statistical calculations and data analysis.

\section{Results and testing hypotheses}

First, the relationship and correlation between variables is tested and the tables of Pearson and Spearman correlation coefficients are presented. It is observable that correlations are significant at the level of 0.01 and 0.05 .

Table 1

The summary of Pearson correlation ratios

\begin{tabular}{|c|c|c|c|c|c|c|}
\hline & & OIS & HCE & SCE & CEE & VAIC \\
\hline \multirow[t]{3}{*}{ OIS } & Pearson Correlation & 1 & $.414^{\prime m}$ & $.596^{* * 1}$ & $.375^{\circ \prime \prime}$ & $.450^{* \prime \prime}$ \\
\hline & Sig. (2-tailed) & & .000 & .000 & .000 & .000 \\
\hline & $\mathrm{N}$ & 1053 & 1053 & 1053 & 1053 & 1053 \\
\hline \multirow[t]{3}{*}{$\mathrm{HCE}$} & Pearson Correlation & $.414^{* *}$ & 1 & $.693^{* 1 *}$ & .036 & $.998^{\circ+7}$ \\
\hline & Sig. (2-tailed) & .000 & & .000 & .241 & .000 \\
\hline & $\mathrm{N}$ & 1053 & 1053 & 1053 & 1053 & 1053 \\
\hline \multirow[t]{3}{*}{ SCE } & Pearson Correlation & $.596^{* *}$ & $.693^{* *}$ & 1 & .040 & $.725^{* \pi}$ \\
\hline & Sig. (2-tailed) & .000 & .000 & & .193 & .000 \\
\hline & $\mathrm{N}$ & 1053 & 1053 & 1053 & 1053 & 1053 \\
\hline \multirow[t]{3}{*}{ CEE } & Pearson Correlation & $.375^{* \prime \prime}$ & .036 & .040 & 1 & $.085^{\text {"N"}}$ \\
\hline & Sig. (2-tailed) & .000 & .241 & .193 & & .006 \\
\hline & $\mathrm{N}$ & 1053 & 1053 & 1053 & 1053 & 1053 \\
\hline \multirow[t]{3}{*}{ VAIC } & Pearson Correlation & .450 & .998 & $.725^{n !}$ & $.085^{\prime \prime \prime}$ & 1 \\
\hline & Sig. (2-tailed) & .000 & .000 & .000 & .006 & \\
\hline & $\mathrm{N}$ & 1053 & 1053 & 1053 & 1053 & 1053 \\
\hline
\end{tabular}

**. Correlation is significant at the 0.01 level (2-tailed) 
Table 2

The summary Spearman's corrlations

\begin{tabular}{|c|c|c|c|c|c|c|c|}
\hline & & & OIS & HCE & SCE & CEE & VAIC \\
\hline \multirow[t]{15}{*}{ Spearman's rho } & OIS & Correlation Coefficient & 1.000 & $.671 * *$ & $.671^{* *}$ & $.411 * *$ & $.699 * *$ \\
\hline & & Sig. (2-tailed) & . & .000 & .000 & .000 & .000 \\
\hline & & $\mathrm{N}$ & 1053 & 1053 & 1053 & 1053 & 1053 \\
\hline & HCE & Correlation Coefficient & $.671 * *$ & 1.000 & $1.000 * *$ & $.076^{*}$ & $.996 * *$ \\
\hline & & Sig. (2-tailed) & .000 & & .000 & .014 & .000 \\
\hline & & $\mathrm{N}$ & 1053 & 1053 & 1053 & 1053 & 1053 \\
\hline & $\mathrm{SCE}$ & Correlation Coefficient & $.671 * *$ & $1.000 * *$ & 1.000 & $.076^{*}$ & $.996 * *$ \\
\hline & & Sig. (2-tailed) & .000 & .000 & . & .014 & .000 \\
\hline & & $\mathrm{N}$ & 1053 & 1053 & 1053 & 1053 & 1053 \\
\hline & CEE & Correlation Coefficient & $.411 * *$ & $.076^{*}$ & $.076^{*}$ & 1.000 & $.153^{* *}$ \\
\hline & & Sig. (2-tailed) & .000 & .014 & .014 & . & .000 \\
\hline & & $\mathrm{N}$ & 1053 & 1053 & 1053 & 1053 & 1053 \\
\hline & VAIC & Correlation Coefficient & $.699 * *$ & $.996 * *$ & $.996 * *$ & $.153 * *$ & 1.000 \\
\hline & & Sig. (2-tailed) & .000 & .000 & .000 & .000 & . \\
\hline & & $\mathrm{N}$ & 1053 & 1053 & 1053 & 1053 & 1053 \\
\hline
\end{tabular}

**. Correlation is significant at the 0.01 level (2-tailed)

*. Correlation is significant at the 0.05 level (2-tailed)

As we can observe from the results of Table 1 and Table 2, there are positive and meaningful relationships between different components of the survey. Table 3 shows details of performing the main hypothesis of the survey. As we can observe from the results of Table 3, F-value is equal to 266.716, which yields a meaningful result. In addition, Durbin-Watson value is within an acceptable limit. Therefore, the main hypothesis of the survey has been confirmed.

Table 3

Model Summary

\begin{tabular}{|c|c|c|c|c|c|c|c|c|c|c|}
\hline \multirow[b]{2}{*}{ Model } & \multirow[b]{2}{*}{$\mathrm{R}$} & \multirow[b]{2}{*}{ R Square } & \multirow[b]{2}{*}{ Adj. $R^{2}$} & \multirow[b]{2}{*}{ Std. Error } & \multicolumn{5}{|c|}{ Change Statistics } & \multirow{2}{*}{$\begin{array}{l}\text { Durbin- } \\
\text { Watson }\end{array}$} \\
\hline & & & & & $\mathrm{R}^{2}$ Change & F Change & df1 & $\mathrm{df} 2$ & Sig. F Change & \\
\hline 1 & $.450^{\mathrm{a}}$ & .202 & .202 & .13612 & .202 & 266.716 & 1 & 1051 & .000 & 1.428 \\
\hline
\end{tabular}

\subsection{The first sub-hypothesis}

The first hypothesis of the survey investigates whether Human capital efficiency of company has a positive relationship with the ratio of operating profit to sales or not. Table 4 shows details of our findings.

Table 4

The summary of regression model

\begin{tabular}{|c|c|c|c|c|c|c|c|c|c|c|c|c|c|}
\hline & \multirow[b]{2}{*}{ Model } & \multicolumn{2}{|c|}{$\begin{array}{l}\text { Unstandardized } \\
\text { Coefficients }\end{array}$} & \multirow{2}{*}{$\begin{array}{c}\begin{array}{c}\text { Standardized } \\
\text { Coefficients }\end{array} \\
\text { Beta } \\
\end{array}$} & \multirow[b]{2}{*}{$\mathrm{t}$} & \multirow[b]{2}{*}{ Sig. } & \multicolumn{2}{|c|}{$\begin{array}{l}95 \% \text { Confidence } \\
\text { Interval for B }\end{array}$} & \multicolumn{3}{|c|}{ Correlations } & \multicolumn{2}{|c|}{$\begin{array}{l}\text { Collinearity } \\
\text { Statistics }\end{array}$} \\
\hline & & B & Std. Error & & & & Lower & Upper & Zero-order & Partial & Part & Tolerance & VIF \\
\hline \multirow[t]{2}{*}{1} & Intercept & .116 & .008 & & 15.272 & .000 & . 101 & .131 & & & & & \\
\hline & VAIC & .024 & .001 & .450 & 16.331 & .000 & .021 & .027 & .450 & .450 & .450 & 1.000 & 1.000 \\
\hline
\end{tabular}

a. Dependent Variable: OIS

The results of Table 4 indicate that there is a positive and meaningful relationship between independent variable and OIS. Therefore, the first sub-hypothesis of the survey has been confirmed. Eq. (6) shows details of our results. 
$O I S=0.116+0.024 V A I C+\varepsilon$

\subsection{The second sub-hypothesis}

The second hypothesis of the survey investigates whether Structural capital efficiency of company has a positive relationship with the ratio of operating profit to sales or not. Table 5 shows details of our findings.

Table 5

The summary of testing the second hypothesis

\begin{tabular}{|c|c|c|c|c|c|c|c|c|c|}
\hline \multirow[b]{2}{*}{$\mathrm{R}$} & \multirow[b]{2}{*}{ R Square } & \multirow{2}{*}{$\begin{array}{c}\text { Adjusted R } \\
\text { Square }\end{array}$} & \multirow{2}{*}{$\begin{array}{l}\text { Std. Error of } \\
\text { the Estimate }\end{array}$} & \multicolumn{5}{|c|}{ Change Statistics } & \multirow{2}{*}{$\begin{array}{l}\text { Durbin- } \\
\text { Watson }\end{array}$} \\
\hline & & & & Change & F Change & $\mathrm{df} 1$ & $\mathrm{df} 2$ & Sig. F Change & \\
\hline $.692^{\mathrm{a}}$ & .478 & .477 & .11019 & .478 & 320.608 & 3 & 1049 & .000 & 1.518 \\
\hline
\end{tabular}

The results of Table 5 also confirms the second hypothesis bringing us to conclude that Structural capital efficiency of company has a positive relationship with the ratio of operating profit to sales.

\subsection{The third sub-hypothesis}

Finally, the last sub-hypothesis of the survey investigates whether employed capital efficiency of company has a positive relationship with the ratio of operating profit to sales or not. Table 6 shows details of our survey.

Table 6

Coefficients

\begin{tabular}{|c|c|c|c|c|c|c|c|c|c|c|c|c|c|}
\hline & \multirow[b]{2}{*}{ Model } & \multicolumn{2}{|c|}{$\begin{array}{c}\text { Unstandardized } \\
\text { Coefficients }\end{array}$} & \multirow{2}{*}{$\begin{array}{c}\text { Standardized } \\
\text { Coefficients } \\
\text { Beta } \\
\end{array}$} & \multirow[b]{2}{*}{$\mathrm{t}$} & \multirow[b]{2}{*}{ Sig. } & \multicolumn{2}{|c|}{$\begin{array}{c}95 \% \text { Confidence } \\
\text { Interval for B }\end{array}$} & \multicolumn{3}{|c|}{ Correlations } & \multicolumn{2}{|c|}{$\begin{array}{c}\text { Collinearity } \\
\text { Statistics }\end{array}$} \\
\hline & & $\mathrm{B}$ & Std. Error & & & & LB & UB & Z-order & Partial & Part & Tolerance & VIF \\
\hline \multirow[t]{4}{*}{1} & Intercept & -.195 & .015 & & -13.304 & .000 & -.224 & -.166 & & & & & \\
\hline & $\mathrm{HCE}$ & .000 & .002 & -.004 & -.122 & .903 & -.004 & .003 & .414 & -.004 & -.003 & .520 & 1.925 \\
\hline & SCE & .487 & .026 & .584 & 18.883 & .000 & .436 & .537 & .596 & .504 & .421 & .519 & 1.925 \\
\hline & CEE & .390 & .025 & .352 & 15.752 & .000 & .342 & .439 & .375 & .437 & .351 & .998 & 1.002 \\
\hline
\end{tabular}

Based on the above table, according to the statistics values of $t$ and calculated significances (lesser than 0.05 ), the equality assumption of most of regression coefficients and fixed value are rejected by the value zero and regression equation, which could be expressed as follows:

$O I S=-0.195+0.487 S C E+0.390 C E E+\varepsilon$.

As the amount of inflation factors of variance is less than 10 , collinearity between independent variables cannot be problematic in using regression. It was also observed that the average of errors are almost zero and standard deviation is close to one, it can also be offered that errors have a normal distribution and using linear regression is correct.

\section{Conclusion}

The main hypothesis of this research at $95 \%$ of confidence level was supported, first subordinate hypothesis was rejected and second and third subordinate hypothesis were supported. Thereby, as the conclusions of Zéghal and Maaloul (2010), intellectual value added coefficient has a positive effect on economic performance. In this research, it was observed that structural capital efficiency and employed capital efficiency had a positive effect on the ratio of operating profit to corporate sales. Among the 
components of intellectual capital it was also observed that structural capital efficiency had the greatest impact on the ratio of operating profit to corporate sales. According to the amount of models R-Square, it can be offered that model capability has more components. Performance of a company is provided by three sources: physical, financial, and intellectual. This issue in value creating compound, is not only related to the invested amounts in physical, financial, and intellectual resources, but also it is totally related to the ability of these resources in value creating.

According to the conducted survey and achieved results, the main research hypothesis was approved, intellectual capital had a positive effect on economic performance of company. It was also observed in studying subordinate hypotheses that the human capital efficiency (in the case of effectiveness) had the least and structural and employed capital efficiency had the most effect on the ratio of operating profit to sales. As the evidences show, notwithstanding the importance of intellectual capital and essential needs to develop and improve it, now physical and financial capital, still have the most impact on performance of studied companies.

In this research, human capital showed the least impact on performance of companies, which can represent lesser privilege given to the management of human resources and perhaps changing the attitude in this regard is essential. Findings of this research can be useful for developing countries, specially, those that have plenty of natural resources but invest so little on human (resources) forces and their own systems and as a result they have lower production and lower growth rate. Finally studying more in the field of intellectual capital and more effort in order to strengthen its economic movements in becoming knowledge-based will be helpful.

\section{References}

Abbasi, E., \& Goldi Sedghi, A. (2010). A study on the effect of efficiency of intellectual capital components on firm financial performance at Tehran Stock Exchange. Accounting and Auditing Reviews, 17(60), 57-74.

Ahangar, R. G. (2011). The relationship between intellectual capital and financial performance: an empirical investigation in an Iranian company. African Journal of Business Management, 5(1), 8895.

Ahuja, B. R., \& Ahuja, N. L. (2012). Intellectual capital approach to performance evaluation: A case study of the banking sector in India. International Research Journal of Finance and Economics, (93), 111-122.

Ahmad, S. B., \& Mushraf, A. M. (2011). The Relationship between Intellectual capital and Business Performance: An empirical study in Iraqi industry. International Proceedings of Economics Development \& Research, 6, 104-109.

Bontis, N., Keow, W. C. C., \& Richardson, S. (2000). Intellectual capital and business performance in Malaysian industries. Journal of Intellectual Capital,1(1), 85-100.

Chen, M. C., Cheng, S. J., \& Hwang, Y. (2005). An empirical investigation of the relationship between intellectual capital and firms' market value and financial performance. Journal of Intellectual Capital, 6(2), 159-176.

Edvinson, L., \& Malone, M. S. (1997). Intellectual capital. Realizing Your Company's True Value by Finding It's Hidden Brainpower. NY, "Harper Business.

Firer, S., \& Williams, S. M. (2003). Intellectual capital and traditional measures of corporate performance. Journal of Intellectual Capital, 4(3), 348-360.

Guthrie, J., Ricceri, F., \& Dumay, J. (2012). Reflections and projections: a decade of intellectual capital accounting research. The British Accounting Review, 44(2), 68-82.

Iswati, S., \& Anshori, M. (2007). The influence of intellectual capital to financial performance at insurance companies in Jakarta Stock Exchange (JSE). In Proceedings of the 13th Asia Pacific Management Conference, Melbourne, Australia (pp. 1393-1399). 
Maditinos, D., Chatzoudes, D., Tsairidis, C., \& Theriou, G. (2011). The impact of intellectual capital on firms' market value and financial performance. Journal of intellectual capital, 12(1), 132-151.

Makki, M. A., \& Lodhi, S. A. (2009). Impact of Intellectual Capital on Return on Investment in Pakistani Corporate Sector. Australian Journal of Basic \& Applied Sciences, 3(3), 2995-3007.

Mohammad, N. A. B., Ansari, M., Ologbo, A. C., \& Rezaei, G. (2013). Investigating The Effect of Intellectual Capital on Organizational Performance and Mediating Role of Entrepreneurial Orientation. International Review of Business Research Papers, 9(3), 99-113.

Mohiuddin, M., Najibullah, S., \& Shahid, A. I. (2006). An exploratory study on intellectual capital performance of the commercial banks in Bangladesh. The Cost and Management, 34(6), 40-54.

Mojtahedzade, V., Alavi Teiri, S.H., and Mehdizade, M. (2010). Relationship between intellectual capital (human, customer, and structural) and performance of insurance industry in the viewpoint of managers. Accounting and Auditing Reviews, 17(60), 109-119.

Moore, L., \& Craig, L. (2008). Intellectual Capital in Enterprise Success. John Wiley \& Sons, Inc., Hoboken: New Jersey.

Murthy, V., \& Mouritsen, J. (2011). The performance of intellectual capital. Journal of intellectual capital, 24, 622-646.

Ngugi, J. K., Gakure, R. W., Susan, W. M., Ngugi, P. K., \& Robinson, K. C. (2012). The Influence of Intellectual Capital on the Growth of Small and Medium Enterprises in Kenya. Journal of Business Management and Corporate Affairs, 1(1), 11-19.

Paturel, R. and Ferchichi, J. (2013). The effect of intellectual capital disclosure on the value creation: An empirical study using Tunisian annual report. International Journal of Accounting and Financial Reporting, 3(1), 81-107.

Petty, R., \& Guthrie, J. (2000). Intellectual capital literature review: measurement, reporting and management. Journal of intellectual capital, 1(2), 155-176.

Pulic, A. (1998). Measuring the performance of intellectual potential in knowledge economy. paper presented at the $2^{\text {nd }}$ World Congress on Measuring and Managing Intellectual Capital, McMaster University, Hamilton.

Pulic, A. (2000), VAICTM - an accounting tool for IC management. International Journal of Technology Management, 20 (5-8), 702-714.

Pulic, A. (2004). Intellectual capital-does it create or destroy value?. Measuring business excellence, 8(1), 62-68.

Rahmani Zarangh, B. (2009). Intellectual Capital Impact on Firm Market Value, Master thesis. Shahid Beheshti University, Tehran.

Setayesh, M. H., \& Kazem Nejad, M. (2009). Studying the effect of intellectual capital on firm performance at Tehran Stock Exchange. Accounting Progresses, 1(1), 69-94.

Shakina. E., \& Barajas. A.(2012). The relationship between intellectual capital quality and corporate performance: An empirical study of Russian and European companies. Economic Annals, 7, 79-97.

Swart, J. (2006). Intellectual capital: disentangling an enigmatic concept. Journal of Intellectual Capital, 7(2), 136-159.

Tan, H. P., Plowman, D., \& Hancock, P. (2007). Intellectual capital and financial returns of companies. Journal of Intellectual Capital, 8(1), 76-95.

Wang, M. S. (2011). Intellectual capital and firm performance. In Annual Conference on Innovations in Business and Management (pp. 1-26). The Center for Innovations in Business and Management Practice.

Zéghal, D., \& Maaloul, A. (2010). Analysing value added as an indicator of intellectual capital and its consequences on company performance. Journal of Intellectual capital, 11(1), 39-60. 